\title{
気候変動による利水への影響を踏まえた ダム貯水池群の最適操作に関する研究
}

\author{
RESEARCH ON THE OPTIMAL OPERATION OF A GROUP OF DAM RESERVOIRS \\ CONSIDERING THE EFFECTS OF CLIMATE CHANGE ON WATER ABAILAVILITY
}

\author{
川村一人 ${ }^{1} \cdot$ 中津川誠 $^{2} \cdot$ 杉原幸樹 $^{3}$ \\ Kazuto KAWAMURA, Makoto NAKATSUGAWA and Kouki SUGIHARA \\ 1 学生会員 室蘭工業大学大学院工学研究科（ \\ 2 正会員 博士(工学) 室蘭工業大学大学院工学研究科（干050-8585 室蘭市水元町 27-1） \\ 3 正会員 理修 (株) 福田水文センター（干001-0024 札幌市北区北 24 条西 15 丁目 2-5）
}

\begin{abstract}
This paper addresses the optimal operation of a group of dam reservoirs in a snowy region for adaptation to the water shortages that are expected to result from climate change. In snowy regions, climate change is likely to cause snow accumulation to decrease. This is expected to shift the snow-melting season earlier, to decrease river discharge and, consequently, to reduce water availability. Thus, the operation of existing dams should be improved. Research was made on the operation of two multipurpose dams in the Toyohira river basin, which supplies water to Sapporo (population 2 million). Using reproductions (1981-2000) and projections (2081-2100) provided by the Regional Climate Model (RCM20) of the Japan Meteorological Agency, we estimated the optimal operation of a group of reservoirs by dynamic programming. The simulation suggests that shortages of dam storage will occur if each dam is operated separately, but that coordinating the discharge operations of two dams can make up for those shortages.
\end{abstract}

Key Words : climate change, snowy regions, optimal operation of a group of dam reservoirs, dynamic programming, measures for adapting to changes in water availability

\section{1. はじめに}

北海道，東北，関東，北陸などの積雪地域では，雪は 貴重な水資源であり，灌泊用水や生活用水，発電用水等 の重要な供給源である.気候変動による気温上昇により, 積雪の減少，融雪期の早期化や融雪出水の減少が予想さ れ，水利用への影響が懸念されている ${ }^{1)}$. 一方，局地的 な豪雨の発生や夏期以外の大雨の増加により治水安全度 の低下も指摘され ${ }^{2)}$ ，その影響に対寸る適応策の検討が 求められている.さらに財政や環境保全上の制約から新 規施設の建設は難しく, 既存施設の有效活用がより重要 となり, 既存ダム運用方法の改善は有効な手段といえる.

ダムの最適操作の代表的な決定法には動的計画法によ る貯水池操作 ${ }^{3), 4)}$ があり, 近年では, 治水では佐山ら ${ }^{5}$, 利水では野原ら ${ }^{6)}$ の研究事例がある. また, 気候変動を 考慮した利水適応策の研究としては Lopez $ら^{7}$ が気候変 動の不確実性を考慮した水資源管理を, Raje ら $^{8)}$ が確率 動的計画法を用いた貯水池最適操作を提案している.

このように気候変動に対する利水適応策の研究が増え てきた中で，日本の積雪地域の水文条件で気候変動を考
慮した利水適応策の研究はあまりされていない。

このような背景から，本研究では，融雪の減少など気 候変動による影響が懸念される積雪地域の利水環境に着 目し, 将来の流出状況の変化と利水一の影響を推定し, それに対する対応策としてダム運用方法について検討し た. ダム運用方法の検討には動的計画法により最適操作 を推定した. 対象流域である豊平川流域には人口約 200 万人の札幌市があり，その水資源管理は重要な課題であ る. 具体的な手順は以下の通りである.

1）気象庁・気象研究所の地域気候モデル RCM $20^{9)}$ のデー タに含まれるバイアスを補正し，現況と将来のダム 流入量を水循環モデルにより試算した。

2）試算した平均ダム流入量と実績利水放流量の月平均 值を用いて，現況と将来の平均的なダム貯水量の変 化を推定するとともに，現況の放流操作で生じる将 来的な水不足に対応できるダム運用を検討した.

3）動的計画法を用いて, ダム単体での放流操作で生じ る問題を示し,ダム連携による最適操作を検討した.

以上により, 単体でのダム操作では将来のダム貯水量 が不足することが示唆され，その対応策としてダムの連 


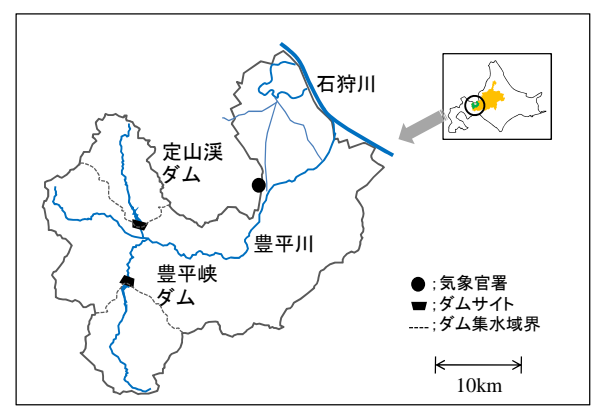

図-1 豊平川流域

携による放流操作が有効であることを動的計画法により 示すことができた.

\section{2. 対象流域の概要}

解析対象は，図-1 に示寸豊平川流域である。豊平川は 流路長 $72.5 \mathrm{~km}$, 流域面積 $960 \mathrm{~km}^{2}$ であり, 札幌市を南北に 貫く河川である. また，札幌市民 200 万人の水道水源の 約 $98 \%$ は豊平川からの取水に依存している. 上流部には 豊平峡ダム (流域面積 $134 \mathrm{~km}^{2}$ ) と定山渓ダム (流域面積 $\left.104 \mathrm{~km}^{2}\right)$ を有し，両ダムともに洪水調節機能および発電・ 水道への利水を目的とした多目的ダムである.

\section{3. ダム貯水量の変化推定}

\section{（1）水循環の定量化手法}

ダム流入量を推定するためには流域内の水循環を求め る必要がある. 本論文では口澤ら ${ }^{10}$ の提案した流域水循 環の定量化手法を利用して求めた. 計算手法の概要を図 -2 に示寸. まず, $1 \mathrm{~km}$ メッシュ単位で蒸発散量, 融雪量, 降雨量を近藤ら ${ }^{11}$ によって提案された 2 層モデルに基づ いた水・熱収支法により求めた. 熱収支は大気一植被層(キ ヤノピー)-地表間の熱フラックスを定式化することで計 算される. 以上により算出した蒸発散量, 融雪量と降雨 量より流出量を算出する. 流出量の推定には, 上流側メ ッシュからの流量をkinematic wave式を用いて河道追跡 し，メッシュ内で生じる流出量を 3 段タンクモデルで計 算し,これらの合計值を下流メッシュへの流入量とした.

\section{(2) メッシュデータ}

水・熱収支計算に用いるメッシュデータは, 川村ら ${ }^{1)}$ が作成したデータを使用した. 作成手法の概要を以下に 示寸。気象データは日単位を基本とし, 気象庁・気象研 究所により開発された地域気候モデル RCM $20^{9}$ の温暖化 予測実験結果を使用した。計算には気温，気圧，風速， 比湿，雲量，降水量，降雪量を使用し，期間は現況期間 の 1981 2000 年と将来期間の 2081 2100年の計 40 年分 の計算を行った．また，気候モデルの再現結果と実際の 観測值の間にはバイアスが含まれるため, モデル出力值 を補正して使用した. バイアス補正手法は藤原ら ${ }^{12)}$ が行

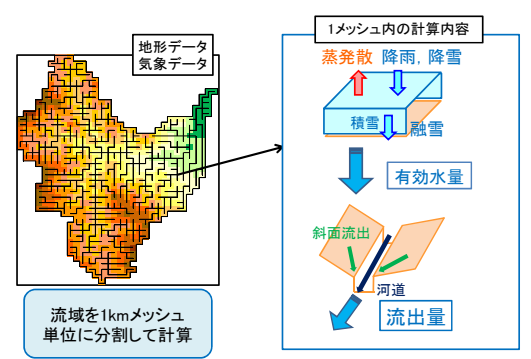

図-2 水循環の定量化手法概要

った月平均気温や月降水量といった月単位での平均值や 分散などの確率分布が保存されるように補正を行う手法 を適用し，ここではRCM20 データと札幌の観測值の確率 分布が合うように, 気温, 降水量, 降雪量, 風速, 湿度 の 5 項目で補正を行った．また，RCM20 の公表データと して提供されていない湿度は気温，気圧，比湿からデー タを作成し，同じく提供されていない日射量は快晴日の 全天日射量の日平均值 ${ }^{11}$ を推定し，それをRCM20 の雲量 で減衰させた值を使用した。 また，水循環計算では相対 湿度を用いた雨雪判別式 ${ }^{11}$ を用いて，降雨か降雪か判別 し, 降雨の場合には降水量データを降雨量として使用し, 降雪の場合には降雪量データを使用して計算を行った.

なお，メッシュデータの作成方法の妥当性に関しては 川村ら ${ }^{11}$ により検証されているので本論文では省略する.

\section{（3）ダム貯水量の計算}

水循環の定量化により求めた流出量の将来変化がダム 貯水量に与える影響について検証するために，ダム貯水 量をモデルにより計算した.

本来のダム貯水池では時間単位での放流操作規則が設 定されているが，本研究では 1 日単位の流出計算を行っ ているので放流操作も 1 日単位を基本としたモデルを作 成した. 計算のモデル化の概略を以下に示す.

\section{a) 操作規則}

豊平峡ダムと定山渓ダムは洪水調節，発電放流，水道 用水を目的として放流が行われている多目的ダムで，流 入量や制限水位といった諸量の関係から放流量が決定さ れる. 治水のためには操作規則に則って放流操作が行わ れているが, 利水放流量の決定には需要量に応じて人為 的な判断が必要となるので峳格なルール化は難しい， ダ 么管理を考える上では渴水年や年々変動の考慮が必要に なるが，将来の変動パターンが流域スケールでどのよう になるかについては評価が定まっていない，また，将来 の水需要量の変化も本研究では考慮していない，そこで 本研究では流入量の平均值を用いたダム操作を考え，現 況，将来ともに実績利水放流量の平均值を用いることで 現況の利水放流操作により生じる将来のダム運用の問題 点とそれへの対応策を検討することとした.

\section{b) ダム流入量}

(1) ダム流入量は現況と将来のダム貯水池運用の課題 を検討するために, 各々 20 年間の平均值を用いた. 


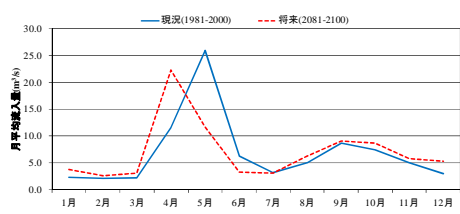

図-3 豊平峡ダムの流入量将来比較

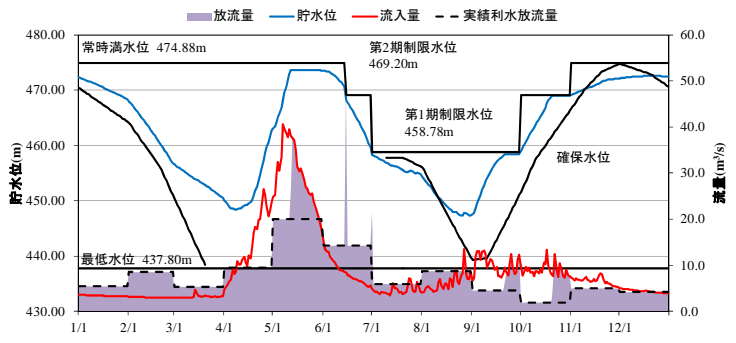

図-5＼cjkstart豊平峡ダムの簡易モデルの現況推定結果

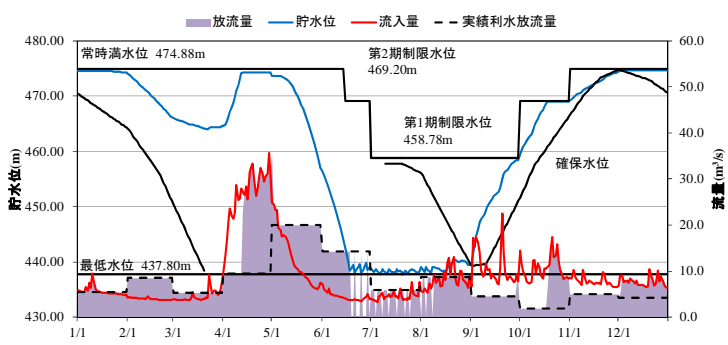

図-7＼cjkstart豊平峡ダムの簡易モデルの将来推定結果

(2) ダム流入量は流出計算過程においてダム堤体のあ るメッシュの流量をダム流入量とした.

(3) 豊平峡ダムでは他流域(薄別川) からの発電用導水 を行っており,それを加味するために現況は発電用 導水実績值(1981〜2000 年)の月平均值を豊平峡夕゙ ムの現況計算流入量に加算し, 将来の水需要は今後 の社会的要因に左右されるため, ここでは現状の水 需要が持続する場合の試算結果を示す. 具体的には 便宜的に発電用導水実績值の月平均值を豊平峡ダ 厶の現況と将来計算月平均流入量の比で補正し, 将 来計算流入量に加算した.

\section{c）ダム放流量}

(1) 利水放流として両ダムでデータのある 1993〜2007 年の 15 年間の実績值の月平均值 $\left(\mathrm{m}^{3} /\right.$ 日) を与えた.

(2) 貯水位が常時満水位または制限水位を超えた場合 には洪水調節を行うものとした。

(3) 放流によって貯水位が最低水位を下回る場合は放 流量を 0 とした.

(4) なお, ダム下流での水道と水力発電の水利権量は最 大でそれぞれ $9.72 \mathrm{~m}^{3} / \mathrm{s}, 15.6 \mathrm{~m}^{3} / \mathrm{s}$ であり，実績取水 量は，水道は 2005，2006 年の平均で $5.16 \mathrm{~m}^{3} / \mathrm{s}$ ，発 電は 1991～1997 年の平均で $9.73 \mathrm{~m}^{3} / \mathrm{s}$ となっている. 上記 a)〜c) で示したダム貯水量の計算モデルを以後, 「簡易モデル」と呼ぶ.

\section{(4) 推定結果と分析}

\section{a）将来予測計算結果の分析}

RCM20 の出力值による現況期間と将来期間の水循環計

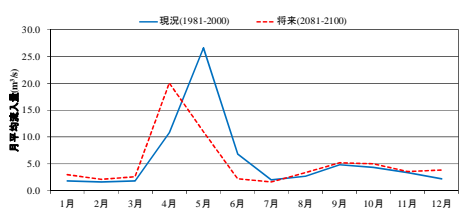

図-4＼cjkstart定山渓ダムの流入量将来比較

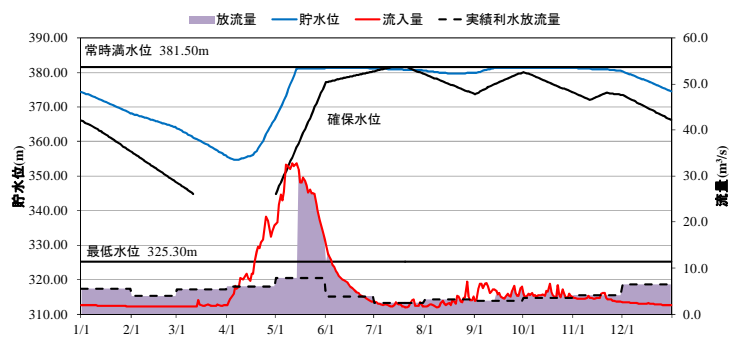

図-6 定山渓ダムの簡易モデルの現況推定結果

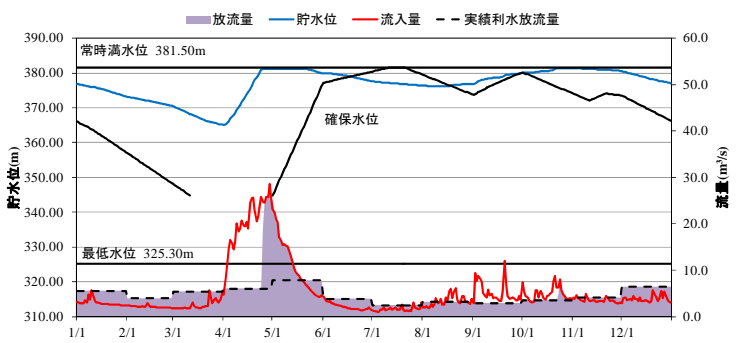

図-8＼cjkstart定山渓ダムの簡易モデルの将来推定結果

算の結果を比較し,利水に与える影響について分析する. 図-3に豊平峡ダム, 図-4に定山渓ダムの現況と将来の月 平均流入量の 20 年平均值を示寸. 図より，両ダムともに 現況の融雪出水のピークが 5 月であるのに対して，融雪 が早まることによって将来の 5 月の流入量は半分以下に 減少し，4 月にピークを迎える結果となった。 また，微 量ではあるが冬期間(12〜2 月)の流入量も増加する結果 となった.

\section{b）ダム貯水池運用の推定結果と分析}

前節で示した簡易モデルを用いて，両ダムの貯水位と 放流量の推定を行った. 図-5に豊平峡ダム, 図-6に定山 渓ダムの現況期間の推定結果を，図-7に豊平峡ダム，図 -8 に定山渓ダムの将来期間の推定結果を示す. 両ダムと もに現況結果では全期間で利水放流分の放流操作を行う ことができ，5月から 6 月に洪水調節が行われる結果と なった. 一方，将来結果については豊平峡ダムでは融雪 出水の早まりによって 4 月の流入量が増加し, 洪水調節 が必要となった. また, 5 月，6月の実績利水放流量は発 電用に多く使われており，将来も同様の放流を行う之 5 月から貯水位が大きく低下し，6 月中旬から 8 月中旬に 利水放流が行えない致命的な状況となることがわかる. 定山渓ダムでも 4 月下旬から 5 月にかけて洪水調節が行 われた．利水放流が行えない日は出現しなかったが，6 月中旬から 8 月中旬に水道用水の供給のために確保す心゙ き水位である確保水位を下回り，利水への影響が䀣念さ れる結果となった．以上より，将来のダム貯水池運用は 現況の放流操作では春期の洪水調節や融雪終了後の夏期 の利水放流に影響を与えることが示唆された. 


\section{4. ダム群最適操作のための動的計画法の適用}

\section{（1）動的計画法のモデルの概要}

前章で示した将来のダム運用の問題点を解決するため に，ダム群の連携操作による対応策を検討する．本論文 ではダム群操作の最適化のために動的計画法を用いて検 討を行った. 動的計画法は R. Bellman ${ }^{13}$ によって提案さ れた数理計画法の一つで，ある目的に対して時間の経過 とともに多段階にわたってなされる決定過程による効果 を数式にモデル化して全体の最適解を得るものであり， ダム群最適操作の決定に適している. 本論文では利水操 作を目的として定式化を行った.その詳細を以下に示寸.

\section{a）变数の定義}

ダム群最適操作の定式化のためにダム貯水池の制御系 に用いる 4 つ変数をそれぞれ次にように決定する．決 定変数は各ダムの放流量 $O_{k}(t)(k=1,2, \cdots, N ; t=1,2, \cdots$, $T)$, 状態変数は各ダムの貯水量 $S_{k}(t)(k=1,2, \cdots, N ; t=1$, $2, \cdots, T)$, 合成変数はダム下流の沿川に設けられた評価 点を通過する流量 $Q_{i}(t)(i=1,2, \cdots, m ; t=1,2, \cdots, T)$, 外 乱は各ダムへの流入量 $I_{k}(t)(k=1,2, \cdots, N ; t=1,2, \cdots, T)$ とする.ここでダムの総数を $N$, 評価地点の総数を $m$, 制御期間の総数を $T$ と寸る. 外乱には残流域からの流量 も含まれるが, 残流域の流量観測データが不十分であり， 取水等の人為的な影響もあるため，安全側評価を考え対 象外とした.

\section{b）制約条件}

ダム操作には貯水池の諸元の物理的または規則上の制 約条件が存在し，それを満たす必要がある．放流量と貯 水量は操作規則により，以下のように表される。

$$
\begin{aligned}
& O_{\text {min }} \leq O_{k}(t) \leq O_{\text {max }} \\
& S_{\text {min }} \leq S_{k}(t) \leq S_{\text {max }}
\end{aligned}
$$

ここで $O_{\min }$ は $0 ， O_{\max }$ は操作規則により定められた最 大放流量, $S_{\text {min }}$ は利水容量が 0 のときの貯水量で, $S_{\text {max }}$ は利水容量が最大のときの貯水量である.

また，ダムの貯水量は次の連続式を用いて表される。

$$
S_{k}(t+1)=S_{k}(t)+I_{k}(t)-O_{k}(t)
$$

\section{c) 目的関数}

最適操作の目的を利水操作とすると最適化の目的は利 水需要量を満たさない場合の被害の最小化といえる。こ こでは池淵ら ${ }^{14)}$ を参考に以下のように定義する.

$$
D_{i}\left\{Q_{i}(t)\right\}=\left\{\begin{array}{cc}
\frac{\left\{Q_{d i}(t)-Q_{i}(t)\right\}^{2}}{Q_{d i}(t)} & \left(Q_{i}(t)<Q_{d i}(t)\right) \\
0 & \left(Q_{i}(t) \geq Q_{d i}(t)\right)
\end{array}\right.
$$

ここで, $D_{i}\left\{Q_{i}(t)\right\}$ は第 $t$ 期における評価地点 $i$ の被害を表 す目的関数, $Q_{d i}(t)$ は第 $t$ 期における評価地点 $i$ の需要量 である.この目的関数を制御期間全てで求め，その和が

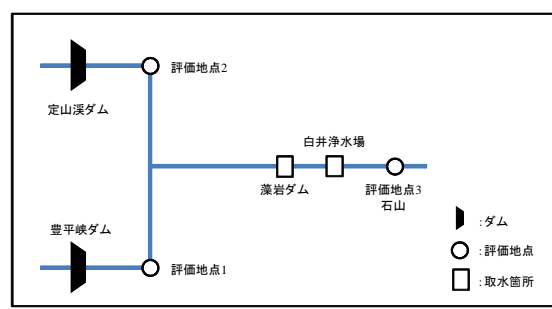

図-9ＤP 連携モデル

最小になるように最適化を行っていく.

d）動的計画法の定式化

設定した目的関数を用いて動的計画法を定式化すると 次式のような評価関数に表現できる.

$$
\begin{aligned}
& f_{t}\left(S_{1}, S_{2}, \cdots, S_{N}\right) \\
& \quad=\min _{\substack{O_{k}(t) \\
S_{k}(t)}}\left\{\sum_{i=1}^{m} D_{i}\left\{Q_{i}(t)\right\}+f_{t+1}\left(S_{1}, S_{2}, \cdots, S_{N}\right)\right\}
\end{aligned}
$$

ここで, $f_{t}\left(S_{1}, S_{2}, \cdots, S_{N}\right)$ は第 $t$ 期から第 $T$ 期までの間の 目的関数の最小值を表す評価関数である. これに対して 後進型の解法を用いると制御期間の第 $T$ 期から第 1 期へ と後進しながら $f_{t}\left(S_{1}, S_{2}, \cdots, S_{N}\right)$ を求めることで最適化問 題を解くことができ，そのためには第 $T$ 期における評価 関数值 $f_{T}\left(S_{1}, S_{2}, \cdots, S_{N}\right)$ を与える必要があり, 以下のよう に表される.

$$
f_{T}\left(S_{1}, S_{2}, \cdots, S_{N}\right)=\min _{O_{k}(t), S_{k}(t)} \sum_{i=1}^{m} D_{i}\left\{Q_{i}(T)\right\}
$$

したがって，式(5)，式(6)より $f_{T}, f_{T-1}, \cdots, f_{1}$ を求めて制 御期間の初期貯水量となる $t=1$ のときの各ダムの貯水 量 $\left(S_{1}(1), S_{2}(1), \cdots, S_{N}(1)\right)$ を与え, $f_{1}\left(S_{1}(1), S_{2}(1), \cdots, S_{N}(1)\right)$ を求めることで全体の最適解を得ることができる.

\section{（2）豊平川流域への適用}

前節で示した動的計画法のモデルを豊平川流域一適用 する. 以下に, 計算に必要な条件を示寸.

\section{a) 流域のモデル化}

豊平川流域は第 3 章で示したように豊平峡ダム，定山 渓ダムという $2 つ の$ 多目的ダムを有しており，下流の水 道用水と水力発電のための放流を行っている.

本研究では，ダム単体での操作を行った簡易モデルの 結果と連携操作による手法を比較するために，豊平川流 域でダム単体での最適化と流域全体での最適化の 2 通り のモデル化を行った. 以後, ダム単体での最適化は「DP 単体モデル」, 流域全体での最適化は「DP 連携モデル」 と呼ぶ. 図-9にDP 連携モデルのイメージ図を示寸. DP 単体モデルの最適化には第 3 章で用いた実績利水放流量 の月平均值を需要量として与えて評価した。一方，DP 連 携モデルでの最適化の場合, ダム単体での最適化に加え て，ダムからの放流が合流したあとの評価地点である石 山でも評価を行った．石山では発電用ダムの藻岩ダムと 
白川取水場があるので，藻岩ダムと白川浄水場の取水水 利権量と石山地点での維持流量の合計值を需要量として 設定した. 最大水利権量はそれぞれ $15.6 \mathrm{~m}^{3} / \mathrm{s} ， 9.72 \mathrm{~m}^{3} / \mathrm{s}$ で，維持流量は定山渓ダム完成後の 1990～2009 年の 20 年間での $1 / 10$ 渇水流量である $0.36 \mathrm{~m}^{3} / \mathrm{s}$ とした.

\section{b) 単位期間，単位量}

動的計画法では，貯水量や放流量，計算対象期間など の諸量は単位量，単位期間を用いて離散化して計算を行 っている. 本研究では計算機の記憶容量と最適化目的が 利水操作であることを考慮して単位期間を5日で1単位, 単位量を 5 日間の平均流量が $1.0 \mathrm{~m}^{3} / \mathrm{s}$ である場合を 1 単 位量とした. よって 1 単位量 $=432,000 \mathrm{~m}^{3}$ となる.

c) 計算条件

計算を行うために前節で設定した制約条件を表-1 に 示す．豊平峡ダムでは利水最大貯水量は洪水期と非洪水 期によって異なり，定山渓ダムでは利水最低貯水量を発 電最低水量に設定した．最大放流量は流入量が利水最大 放流量より小さい場合は利水最大放流量に設定し，その 逆の流入量が利水最大放流量より大きい場合は洪水調節 開始流量の $60 \mathrm{~m}^{3} / \mathrm{s}$ を上限として流入量分を放流できる ように設定した．また，石山地点での流量の下限值とし て水道用水の実績取水量の年平均值 $5.16 \mathrm{~m}^{3} / \mathrm{s}(2005,2006$ 年) と $1 / 10$ 渇水流量の $0.36 \mathrm{~m}^{3} / \mathrm{s}$ の合計值は下回らない ように条件を設定した。

初期条件と単位期間の最終条件として与えるダムの貯 水量は簡易モデルで求めたダム貯水量の 1 月 1 日の值を 現況, 将来それぞれの值を設定して計算を行った.

\section{5. 計算結果と分析}

\section{（1）ダム単体操作の結果と分析}

まず，簡易モデルで求めたダム貯水量の推定結果と同 条件の DP 単体モデルでの推定結果を比較する. 図-10に 豊平峡ダムの現況推定結果を, 図-11 に豊平峡ダムの将 来推定結果を示す。簡易モデルより求めた推定結果と計 算の単位期間は異なるが, DP 単体モデルで求めた現況結 果は全期間で利水放流を行うことができ，将来結果では 6 月中旬から 8 月中旬にかけて放流量 0 の日が出現しな いように 5 月，6月の放流量を減ら寸傾向が見られ，そ れでも 7 月から 9 月にかけては貯水位が最低水位近くを 推移する結果となり，簡易モデルで求めた結果と近い結 果が得られた．定山渓ダムでも同様の傾向が見られ，単 体でのダム操作では最適操作を行ったとしても将来的に 利水へ支障をきたす可能性が示唆された.

\section{（2）ダム連携操作の結果と分析}

\section{a) 現況推定結果}

単体でのダム操作での問題点を解決するために，ダム の連携操作による対応策を考えた。 まず，DP連携モデル での現況の推定結果を示し，連携操作による最適操作に
表-1 両ダムの制約条件

\begin{tabular}{|c|c|c|c|c|c|c|c|}
\hline & \multicolumn{3}{|c|}{ 利水最大貯水量 $\left(\mathrm{m}^{3}\right)$} & \multirow{3}{*}{$\begin{array}{l}\text { 利水最低 } \\
\text { 貯水量 }\left(\mathrm{m}^{3}\right)\end{array}$} & \multicolumn{3}{|c|}{ 放流量 $\left(\mathrm{m}^{3} / \mathrm{s}\right)$} \\
\hline & 非洪水期 & 第1期洪水期 & 第2期洪水期 & & & & \\
\hline & $\begin{array}{c}1 / 1 \sim 6 / 14 \\
11 / 1 \sim 12 / 31 \\
\end{array}$ & $7 / 1 \sim 9 / 30$ & $\begin{array}{r}6 / 15 \sim 6 / 30 \\
10 / 1 \sim 10 / 31 \\
\end{array}$ & & 最小值 & 流入咅〈利水 & 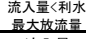 \\
\hline 豊平峡ダム & $37,100,000$ & $16,900,000$ & $29,000,000$ & 0 & 0 & 26.4 & 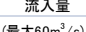 \\
\hline 定山溪ダム & & & $59,600,000$ & $11,200,000$ & 0 & 10.0 & $\begin{array}{c}\text { 流入量 } \\
\left(\text { 最大 } 6 \mathrm{~m}^{3} / \mathrm{s}\right)\end{array}$ \\
\hline
\end{tabular}

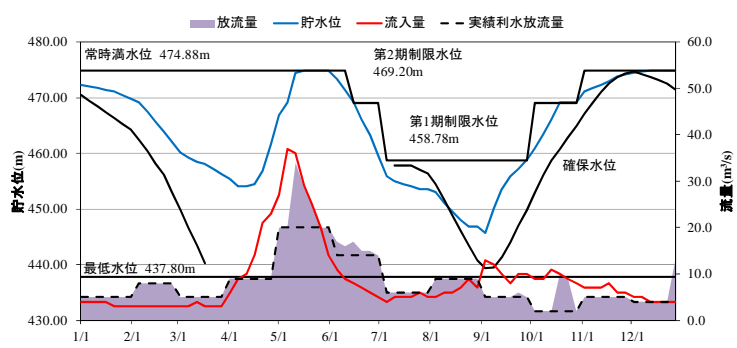

図-10 豊平峡ダム現況のDP 単体モデルの推定結果

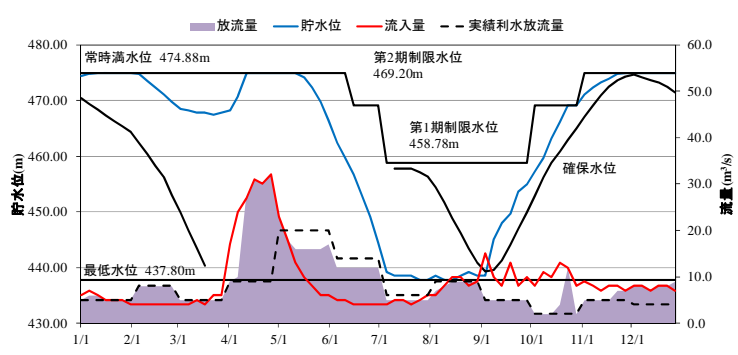

図-11豊平峡ダム将来のDP 単体モデルの推定結果

ついて検討した. 図-12 に豊平峡ダム, 図-13に定山渓ダ ムの DP 連携モデルによる現況推定結果をそれぞれ示寸. 結果より簡易モデルに比べて，豊平峡ダムの 2 月から 4 月や定山渓ダムの 1 月から 3 月など利水需要量より多く 放流している期間があり，これは下流の需要量を満たす ために放流を多くしているためである．また，流入量が 多くなる融雪期を前にダム貯水位を最低水位近くまで下 げて，なるべく洪水調節をしないような操作を行ってい る. 以上より，連携操作では両ダムの状況を見ながら下 流の需要を満たす放流が可能である結果となった.

\section{b) 将来推定結果}

次に, DP 連携モデルによる将来の推定結果を示し, 将 来の水不足に対する対応策としての連携操作の有用性を 検討した．図-14 に豊平峡ダム，図-15に定山渓ダムの DP 連携モデルによる将来推定結果をそれぞれ示寸．DP 単体モデルの結果と比較して，豊平峡ダムでは 5 月，6 月の利水放流量を減らすことで貯水位をなるべく高い状 態を維持し， 7 月から 9 月までの貯水位が大きく低下す ることはなく，放流を行うことができている．また，豊 平峡ダムからの放流が減る分は定山渓ダムからの放流を 増や寸ことで補っており, ダムの連携操作によって下流 の水需要を満たしつつ，ダムの貯水量が不足するような 状態を回避することが可能であることを示した.

\section{6. まとめ}

本報告で得られた結果を以下にまとめる。

1）気象庁・気象研究所の地域気候モデル (RCM20) の温 


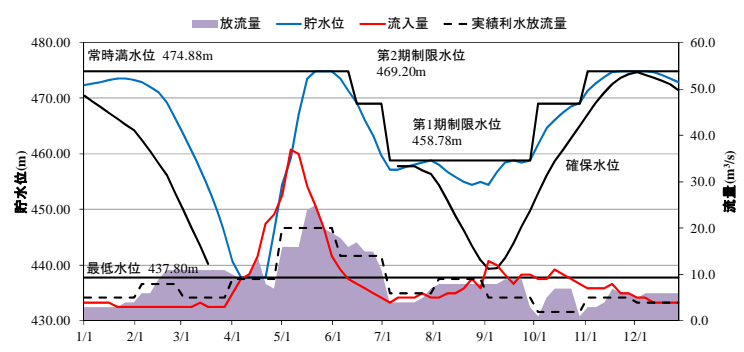

図-12 豊平峡ダム現況の DP 連携モデルの推定結果

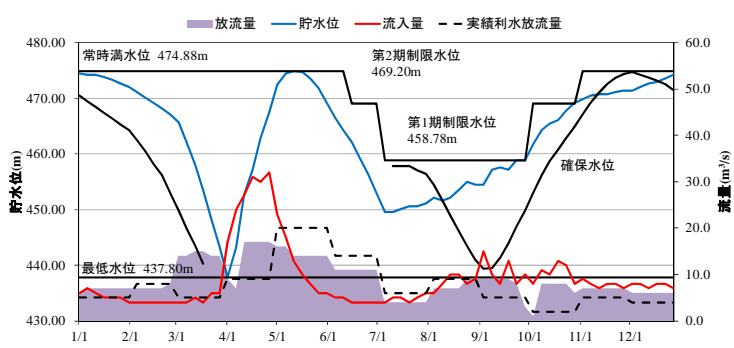

図-14＼cjkstart豊平峡ダム将来のDP 連携モデルの推定結果

暖化予測実験結果のバイアス補正したデータを用い て現況と将来の水循環計算を行い，将来的な流出量 の変化を推定した.

2）現況と将来の平均的なダム貯水位と放流量を推定し, 豊平峡ダムでは 6 月中旬から 8 月中旬に貯水位が大 幅に低下し, 利水放流を行えない日が出現し, 利水一 の影響が懸念された。

3）動的計画法を用いてダムの最適操作を検討し，ダム の単体操作で生じる水不足は，ダムの連携操作によ り回避可能であることを示した.

今後の課題として，実時間操作といった管理問題への 展開を考え，流入量の不確害性を考慮できるように予測 情報や確率DP の適用などを検討していきたい.

謝辞 : 本研究の一部は学術研究助成基金助成金基盤研究 (C) (課題番号 23560602) と平成 22 年度河川整備基金 (助 成番号 22-1211-002）の助成を受けた. また, 気象庁地 球環境・海洋部気候情報課からは地域気候モデル (RCM20) の気候変化予測結果を提供いただいた．また，北海道開 発局にはデータ提供等で劦力いただいた. ここに記して 謝意を示す.

\section{参考文献}

1) 川村一人, 中津川誠 : 気候変動下における積雪地域の利 水一の影響を踏まえたダム管理のあり方について，河川 技術論文集，第17 巻，pp.287-292，2011.

2) 臼谷友秀, 中津川誠 : 北海道における冬期温暖化の傾向 と水循環へ与える影響, 地球環境シンポジウム論文集, 13, pp.1-6, 2005.

3) 竹内邦良: 貯水量の累加損失係数を用いた貯水池群の最 適操作手法, 土木学会論文報告集, 第222 号, pp.93-103, 1974.

4) 高棹琢馬，池淵周一，小尻利治 : 水量制御からみたダム

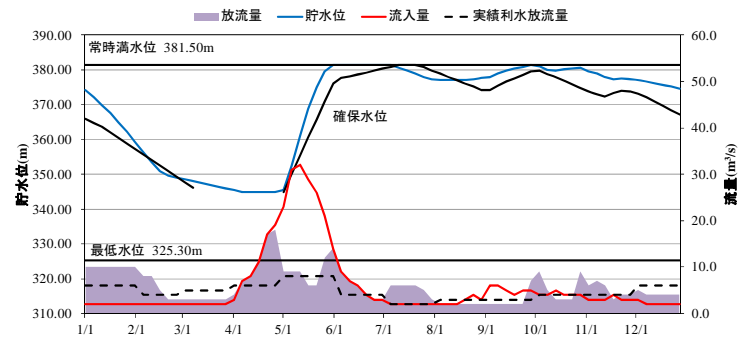

図-13 定山渓ダム現況の DP 連携モデルの推定結果

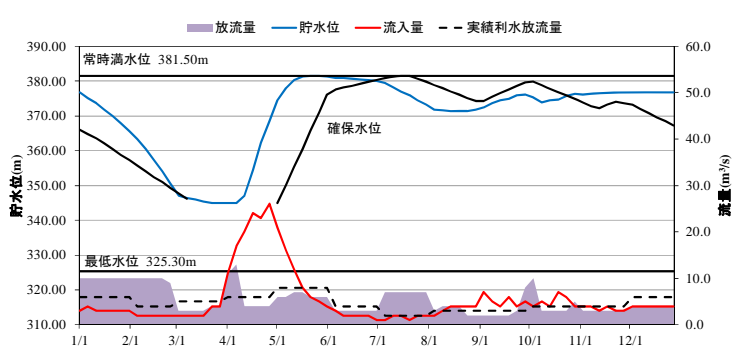

図-15＼cjkstart定山渓ダム将来の DP 連携モデルの推定結果

群のシステム設計に関する DP 論的研究, 土木学会論文報 告集，第241号，pp.39-50， 1975.

5) 佐山敬洋，立川康人，菅野浩樹，寶馨 : 分布型流出モデ ルと動的計画法の結合による貯水池制御最適化シミュレ 一夕の開発，水工学論文集，第 54 巻，pp.547-552， 2010.

6) 野原大督, 坪井亜美, 堀智晴 : 長期貯水池操作へのアン サンブル降水予報導入時における最適化モデルの放流決 定過程に関する一考察, 京都大学防災研究所年報, 第 52 号 B, pp.753-764, 2009.

7) Lopez A, Fung F, New M, Watts G, Weston and A, Wilby R.L. :From climate model ensembles to climate change impacts and adaptation: A case study of water resource management in the southwest of England, Water Rresources Research, 45,W08419, doi:10.1029/2008WR007499, 2009.

8) Raje D, Mujumdar P.P. : Reservoir performance under uncertainty in hydrologic impacts of climate change, Advances in Water Resources, 33, pp.312-326, 2010.

9) 気象庁, 地球温暖化予測情報第 6 巻 IPCC の SRESA2 シ ナリオを用いた地域気候モデルおよび都市気候モデルに よる気候予測, 2005.

10） 口澤寿，中津川誠 : 熱・水収支を考慮した流域スケール の積雪と蒸発散の推定，北海道開発土木研究所月報，

No.588, pp.19-38, 2002.

11）近藤純正編著：水環境の気象学，朝倉書店，1994.

12）藤原洋一，大出真理子，小尻利治，友杉邦雄，入江洋樹： 地球温暖化が利根川上流域の水資源に及ぼす影響評価, 水工学論文集, 第 50 巻, pp.367-372, 2006.

13) Bellman R : Dynamic Programming, 340 pp., Princeton University Press, Princeton, New Jersey, 1957.

14）池淵周一，小尻利治，宮川裕史：中・長期気象予報を利 用したダム貯水池の長期実時間操作に関寸る研究，京都 大学防災研究所年報, 第33 号 B-2, pp.167-192，1990.

(2011.9. 30 受付) 